Article

\title{
Evaluating the Potential Business Benefits of Ecodesign Implementation: A Logic Model Approach
}

\author{
Vinícius P. Rodrigues ${ }^{1,2, *}$ (1) , Daniela C. A. Pigosso ${ }^{1}$ (D) , Jakob W. Andersen ${ }^{1}$ \\ and Tim C. McAloone ${ }^{1}$ \\ 1 Department of Mechanical Engineering, Technical University of Denmark, 2800 Kgs. Lyngby, Denmark; \\ danpi@dtu.dk (D.C.A.P.); jawan@dtu.dk (J.W.A.); tmca@dtu.dk (T.C.M.) \\ 2 Insper, Rua Quatá 300, Vila Olímpia, 04546-042 São Paulo, Brazil \\ * Correspondence: vipiro@dtu.dk
}

Received: 17 May 2018; Accepted: 12 June 2018; Published: 14 June 2018

\begin{abstract}
The business benefits attained from ecodesign programs in manufacturing companies have been regularly documented by several studies from both the academic and corporate spheres. However, there are still significant challenges for adopting ecodesign, especially regarding the evaluation of these potential business benefits prior to the actual ecodesign implementation. To address such gap, this study proposes an exploratory and theory-driven framework based on logic models to support the development of business cases for ecodesign implementation. The objective is to offer an outlook into how ecodesign implementation can potentially affect key corporate performance outcomes. This paper is based on a three-stage research methodology with six steps. Two full systematic literature reviews were performed, along with two thematic analyses and a grounded theory approach with the aim of developing the business case framework, which was then evaluated by seven industry experts. This research contributes to the literature of ecodesign especially by laying out an ecodesign-instantiated logic model, which is readily available to be adapted and customized for further test and use in practice. Discussions on the usefulness and applicability of the framework and directions for future research are presented.
\end{abstract}

Keywords: ecodesign implementation; business case; logic model; sustainable product development; performance framework; ecodesign maturity model

\section{Introduction}

Practitioners and researchers have been continuously reporting potential business benefits achieved by the implementation of ecodesign efforts within corporate contexts, e.g., higher innovation level [1,2], increased revenue and development of new markets and business models [3,4], risk and cost reduction [5,6], brand equity [7-9], compliance [10-12], among others. However, many challenges still hamper the identification of the business benefits related to the implementation of ecodesign, especially in regards to the lack of evaluation mechanisms for the potential benefits for the business performance [13-16]. In addition, ecodesign efforts have been intensely focused on assessing performance from a pure environmental perspective with a strong emphasis on the product's technical features, such as shape, material or energy consumption $[17,18]$. Low levels of attention have been positioned on organizational processes underpinning the adoption and maintenance of ecodesign $[1,17]$. The underlying rationale of the process-oriented approach is that by tackling ecodesign implementation at the process level, companies will assure consistent integration and alignment across the company's portfolio-i.e., improved product development processes will result in products with enhanced sustainability performance [19] and business outcomes. 
Given that the reported business benefits emerging from ecodesign usually exceed the environmental dimension of business performance-such as emissions, pollution, energy consumption, materials usage etc.- a triple bottom line approach aimed at enabling and enhancing the managerial and process-oriented perspective of the implementation is required [20-22] to deriving a consistent business case for action. The business case for sustainability-related efforts and initiatives have been increasingly discussed in the literature for several decades [23,24]. In short, a business case can be understood as a collection of arguments and lines of thought that support and document the main reasons why an organization should accept or advance a certain cause [24,25].

The concept of business cases for sustainability-related initiatives touches upon considering and exploring the existing relationships between voluntary environmental and social activities and corporate economic success [26], alongside questions regarding how to manage, advance and innovate on those relationships. However, the majority of the business cases in the literature account for a posteriori analysis of the effects of past sustainability-related practices, projects or programs $[2,4,6]$, as opposed to an a priori, predictive business cases, which are focused on laying out the theoretical foundation for collecting information and measuring the performance of sustainability-related efforts in a proactive fashion towards deriving a subsequent business case.

Within this context, logic models have become a popular way of identifying the elements of a program's design, operation and its effects [27]. The logic model depicts the logical sequence of events to occur through an initiative or intervention to bring change as a response to a current specific state [28]. In the logic model, a collection of inputs underpins the execution of certain activities, which produces direct effects (outputs) [29,30]. These outputs can eventually influence longer-term performance and goals, which are typically depicted in the logic model, known as outcomes/impact [29,31,32]. The degree of tangibility varies across the levels of the logic model, from the inputs/resources to the outputs and outcomes/impact. In summary, the logic model can be a representative framework of an initiative's potential to influence performance, and the sequential logic behind this influence.

With that, the research draws upon the particular concept of ecodesign management practice [19], and seeks to offer an integrative outlook into how ecodesign capabilities will potentially affect corporate performance over time (e.g., revenue, market share, expenses, risk etc.). The focus of this research is positioned at investigating ecodesign from a process perspective within the corporate sphere. With that, this research addresses the following questions: (1) how does the implementation of ecodesign management practices can potentially affect corporate performance? (2) how can logic models support conceptualization and evaluation of the relationships between ecodesign practices and business benefits? The study proposes an exploratory, theory-driven logic model framework to support the development of business cases for ecodesign, targeted at key managers and decision-makers across the organization. This exploratory research goes further into qualitatively linking the development of ecodesign management capabilities with its potential business benefits. This piece of research largely contributes to the literature of ecodesign in by offering an ecodesign-instantiated logic model framework, which is readily available for practical use. Furthermore, the research develops and offers a logic model framework based on which other quantitative and qualitative methods can be developed and added in order to achieve more robust measurement mechanisms for potential ecodesign business benefits.

\section{Theoretical Background}

This section briefly presents and discusses the two main constituents of the theoretical background of this research: (i) the Ecodesign Maturity Model (EcoM2) and (ii) the general theory of logic models. In particular, the EcoM2 was selected as the theoretical background of this research because it is established in the literature and it is the only available framework that offers a maturity-based and systematic approach to ecodesign implementation and management [33], as of today. Additionally, the EcoM2 has been adopted in several large multinational manufacturing companies (see, for example, [34-36]). 


\subsection{The Ecodesign Maturity Model (EcoM2)}

The EcoM2 is a management framework geared towards supporting the systematic integration of ecodesign into the product development processes (e.g., strategy, value chain, marketing, logistics etc.) [19]. The model has been recently enhanced with mangement practices coming from the product/service-systems (PSS) [37,38] and the social innovation [39] fields, integrating the business and social aspects, which have been typically overlooked within the product development space $[17,40,41]$. Three fundamental elements are part of the EcoM2 [19]: (i) ecodesign management practices; (ii) maturity levels and (iii) an application method, which are further described.

\subsubsection{The EcoM2 Practices}

The practices in the EcoM2 framework form a consistent body of knowledge and can be categorized into management and operational practices [19]. The management practices are fundamentally related to the integration of ecodesign at the strategic and tactical levels of product development, whereas the operational ones are product-specific and intimately attached to the technical features and charactrersitics of a the design and life cycle of a particular product (or line of products) [19]. While the management practices are process-oriented and generic, threfore being applicable to any type of manufacturing company-irrespective of the product's specific characteristics [19] — the operational ones are product-oriented, and therefore, specific. As a convention, all best practices in the EcoM2 (at a process level) will be reffered as ecodesign management practices (EMP), since this is an established nomenclature within the EcoM2 framework and across its updates over time. The EMPs are the main object (unit of analysis) of this paper. The total number of EMPs in the EcoM2 is fifty-one.

Examples of ecodesign management practices include [19,37,39]: (i) "monitor the product environmental performance during use and end-of-life phases of the life cycle" [38] (p. 218); (ii) "consider and involve the total value chain for improving the environmental performance of products" [38] (p. 217); (iii) "collect information about legal issues and standards related to the environmental performance of products" [38] (p. 216); (iv) "incorporate environmental considerations into the technological strategy" [38] (p. 216) and (v) "identify customers' and stakeholders' requirements and priorities concerning the environmental issues" [38] (p. 216). These practices are therefore related to the product development processes, as opposed to particular characteristics of a company's products. In this sense, the management practices take a process standpoint which aims at integrating the entire company's portfolio of products.

\subsubsection{The EcoM2 Maturity Levels}

The maturity levels are defined according to a grouping of two variables [19]: (i) the evolution levels and (ii) the capability levels $[19,42]$ of the management practices. The five evolution levels defined by the EcoM2 represent a recommendation of the stages to be trailed towards ecodesign implementation. The evolution is built from evolution level 1 , in which the company displays little experience in ecodesign and the company does not typically apply ecodesign practices, up to evolution level 5 , when the company fully incorporate environmental concerns into its corporate, business and product strategies [19]. Regarding the capability levels, the model also defines a 5-point capability scale for qualitatively measuring how well the company applies an ecodesign management practices, based on the CMMI [19,43]. The capability levels are [19]:

- Capability level 1 (incomplete) means that a practice is not contemplated by the company or is partly applied in incomplete way;

- Capability level 2 (ad hoc) means that a practice is only applied to accomplish specific tasks or correct targeted problems, i.e., in an ad hoc format;

- Capability level 3 (formalized) means that the practice is formalized and documented in processes, with allocated resources, infrastructure and responsibilities;

- Capability level 4 (controlled) means that the management practice has its performance measured and constantly controlled with the application and use of process-related indicators; 
- Capability level 5 (improved) means that the management practice has its performance continuously improved over time, based on measurement and monitoring.

\subsubsection{The EcoM2 Application Method}

The EcoM2 prescribes an application method with 4 steps, which are being represented here as an adaptation from [19] organized in two main phases. Figure 1 displays the schematic representation of the EcoM2 application method, with the main outputs and the positioning of the business case. Phase 1 consists of 3 steps:

- the diagnosis involves the definition of the company's current maturity profile, whose main output is the current capability levels of the management practices;

- the definition of a vision for improved maturity, according to a corporate vision and strategic drivers, and whose main output is the desired capability levels for the management practices and

- the deployment of actionable roadmaps for implementation, based on the identified gap between the current capability levels (Step 1) and desired capability levels (Step 2).

The second phase embodies the implementation of the improvement projects. These projects are detailed and outlined in the roadmaps, accompained by strategies and best practices for change management and performance measurement and tracking [19]. The business case plays a crucial role in bridging the gap between the deployment of structured roadmaps and their real and consistent implementation. The business case for ecodesign implementation should be used in order to bridge the gap between the deployment of roadmaps and action plans and the actual implementation of such roadmaps, which will ultimately result in higher levels of ecodesign maturity.

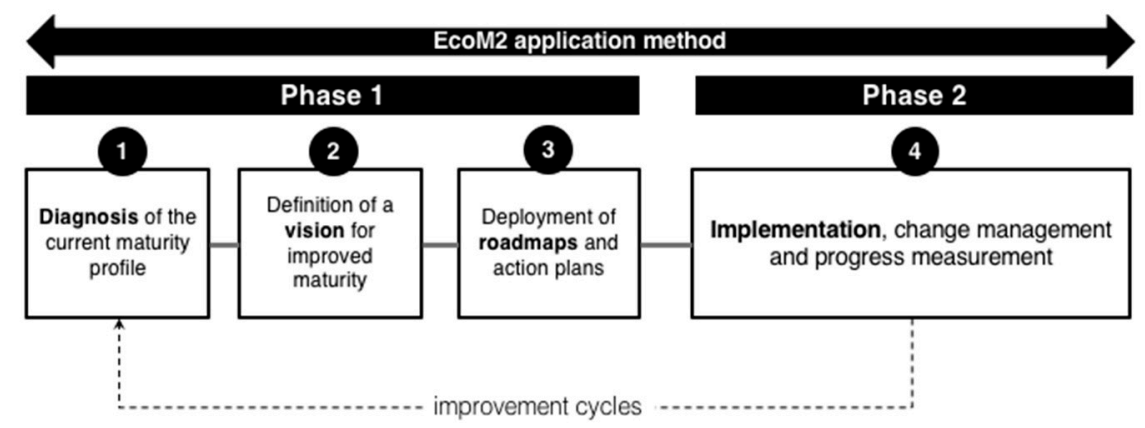

Figure 1. Adaptation of the schematic representation of the EcoM2 application method from [19].

\subsection{Logic Models: The Structure Underpinning the Business Case Rationale}

A logic model can be defined as a systematic and visual tool to present and share an organization's understanding of the relationships among the resources required to operate a program, its related activities, and the intended changes or results [30]. In the logic model, a set of resources (or inputs) activities are all the actions that are necessary to produce desired direct results, commonly named outputs $[29,30,44]$. These outputs will, in turn, generate outcomes, which are changes in behavior, knowledge, skills, status or level of functioning [29-32]. Outcomes are typically less tangible as they are not the immediate results of an action. Therefore, the logic model is particularly useful to depicting the underlying assumptions and bases upon which the ecodesign practices are expected to lead to the occurrence of another event [45].

Through a logic model lens, the ecodesign management practices can be defined and seen as activities that are embedded into the product development and related processes. Once these activities are carried out, they produce direct results (outputs) which, in turn, create changes or benefits (outcomes) at a more aggregated level in an organization [46]. This line of reasoning-connecting activities and their resources to ultimate changes/benefits-is known as logic model (or theory of 
change or performance frameworks or chains of reasoning) [27,47]. Logic models are particularly useful to plan, manage, account for, assess or evaluate the relationships between what a program (i.e., set of activities) requests in terms of resources and which accomplishments are sought [45]. It is noteworthy that in real contexts, there is a wealth of interaction between outputs and outcomes, and relationships are not always one-to-one. Figure 2 displays a hypothetical example of a logic model structure for a physical artifact. It is noteworthy that in real contexts, there is a wealth of interaction between outputs and outcomes, and relationships are not always one-to-one.

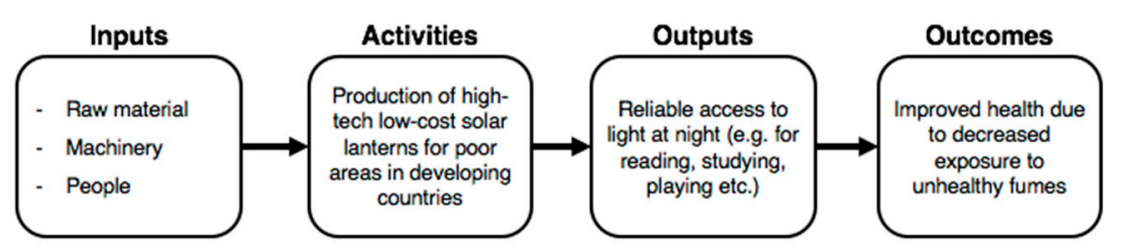

Figure 2. Generic structure of a logic model with a hypothetical example of ecodesign-related initiative. Structure adapted from [48].

\section{Research Methodology}

The general research approach was composed of three main phases, which are separated in six steps (Figure 3).

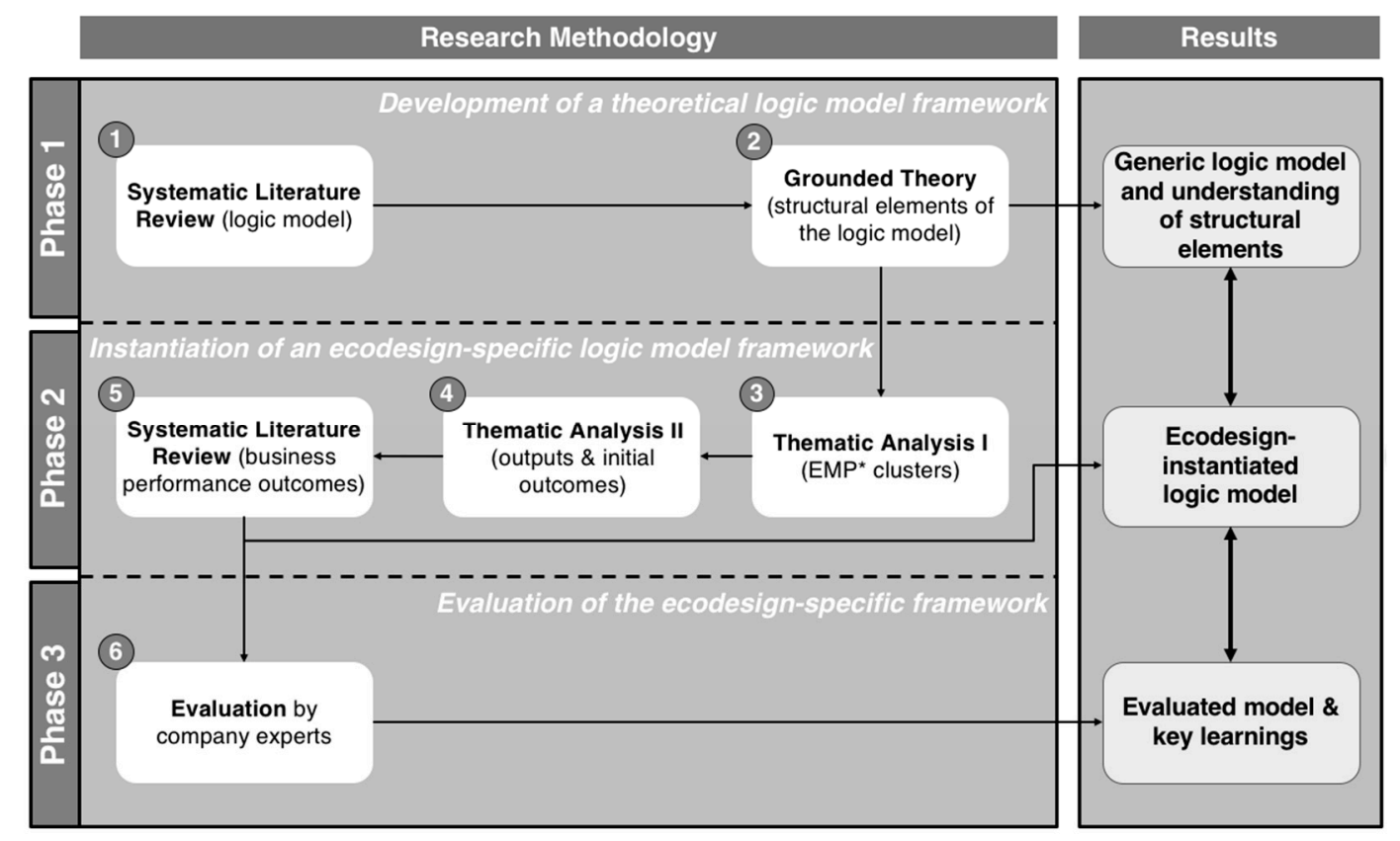

Figure 3. Overall research approach of this paper with 3 phases and 6 steps (* EMP: ecodesign management practices).

\subsection{Phase 1: Development of a Theoretical Logic Model Framework}

The first step (Step 1) put forward a systematic literature review (SLR) based on the methodology prescribed by [49], which builds upon the three sub-steps: (1) planning of the review process; (2) execution of the SLR and (3) analysis of results. The selection and evaluation procedures were performed in accordance to the inclusion criteria defined by the protocol. For each one of the selected studies, relevant data were captured, cataloged and analyzed [49].

The main objective of the SLR was to identify the structural elements of the logic models proposed or analyzed by the academic literature. The search string was composed of the main keyword 
("logic model") and three other relevant and recurrent synonyms ("theory of change", "performance framework" and "chain of reasoning") [27,47] were added to the title field of the search string. Two electronic databases were used, namely Web of Science and Scopus, due to their high relevance and coverage. The searches were limited to documents originally written in English only.

Subsequently, the second step (Step 2) comprised an approach built upon grounded theory [50-52], accompanied by a content analysis. It was performed in order to examine and elicit emerging patterns within the data corpus [53,54]. The grounded theory approach was also aided by a content analysis [55] of generic business process management and practices within organizational contexts [22,56-58]. The combination of the SLR with the grounded theory approach on Phase 1 gave rise to a fundamental understanding of the logic model theory and an overview of its structural elements.

\subsection{Phase 2: Instantiation of an Ecodesign-Specific Logic Model Framework}

The second started with the performance of a thematic analysis focused on (i) deriving thematic clusters of ecodesign management practices (Step 3); (ii) developing specific outputs and outcomes for each one of the ecodesign management practices in the EcoM2 (Step 4) and (iii) systematically reviewing the literature in order to derive a database of business performance outcomes (Step 5). The main objective of deriving thematic clusters of practices was to facilitate the evaluation and application of the logic model framework by companies, according to their own drivers or requirements. The outputs and outcomes generated in this phase would then compose the instantiation of the ecodesign-specific logic model framework.

Thematic analysis is a method for capturing and analyzing themes/patterns within a body of data $[59,60]$. In our case, the body of data was composed of all the 51 ecodesign management practices present in the EcoM2. Moreover, the thematic analysis had an inductive approach, i.e., the themes / patterns emerged exclusively from the data, without any attempts to fitting them into a larger theoretical frame [53]. Also, the ecodesign management practices display commonalities and recurring themes, which makes thematic analysis an adequate method for analysis [53].

For Step 3 (Thematic Analysis I), the thematic analysis focused on deriving clusters of ecodesign management practices. Subsequently, Step 4 (Thematic Analysis II) focused on the main aspects of generic activities within the product development space and the fundamental content of each one of the ecodesign management practices in order to develop a consistent list of outputs and outcomes. This thematic analysis had the main objective of understanding how management practices could potentially fit into the generic structure of the logic model. Furthermore, triangulation methods were used in order to improve research rigor, validity and trustworthiness [52]. In particular, investigator triangulation [61,62] was applied, entailing that multiple researchers conduct the analytical process in an attempt to significantly reduce bias. In these particular steps of the research approach, the authors analyzed the data separately and held three subsequent meetings to discuss and compare the emerging themes until agreement was finally reached for all elements.

The following (Step 5) involved a focused SLR, also based on the procedure set forth by [49], which was further detailed in the beginning of Section 3.1. The main objective of this second SLR was to identify which outcomes were being generally reported as relevant and strategic business benefits in the literature, and to which dimensions of the triple bottom line the outcomes were related. No restrictions were derived in terms of what types of business were reporting the benefits. Three main keyword groups were defined, along with their related keywords: (i) "corporate" and seven related keywords ("enterprise", "organizational", "organisational", "financial", "business", "market", "competit"); (ii) "performance" and one related keyword ("bottom line") and (iii) "indicator" and seven related keywords ("measure", "metric", "index", "indices", "framework", "map", "score"). The keywords were inserted into the title field of the search string on the Web of Science database. Searches were limited to cover documents in English only. 


\subsection{Phase 3: Evaluation of the Ecodesign-Specific Logic Model Framework}

The evaluation by experts (Step 6) was performed with the purpose of improving the validity of the proposed ecodesign-specific logic model framework. The workshops were aimed at: (a) validating the most relevant business performance outcomes based on selection of three companies in different industry sectors and (b) having the underlying rationale of the ecodesign-specific logic model evaluated by the experts, in terms of usefulness and applicability in their own organizations. The evaluation process took place under a series of three workshops, with an average duration of two hours each. Seven impartial industry experts-representing three companies from different industry sectors-participated in the evaluation phase.

It is very important to highlight that the workshop-based process of evaluation was highly structured and standardized, with all the workshop session rigorously following the steps described under this section. All the sessions were based on structured procedures and rules, which applied to all three of them. The evaluation procedure was performed with a total of 7 experts, with carefully documented and selected backgrounds and experiences. This particular number of experts contributes to maximizing the probability of replicating the results reported in this paper. If the evaluation was carried out with only one or two experts, results would be hardly replicated since they would be largely dependent on individual answers and standpoints. On the other hand, since there is a "saturation effect" in such a structured evaluation procedure, a larger number of experts might have probably had very little marginal contribution to the overall results and the contributions of this study.

More particularly, the organizations and experts were selected on the basis of their relevant overall exposure to recent ecodesign program implementations within the context of product development processes. In particular, the selected companies had varying degrees of exposure to the EcoM2 framework, ranging from pure awareness to full implementation. However, their knowledge of the EcoM2 was not defined as a criterion mainly because it is not required to be familiar with the EcoM2 in order to apply and evaluate the logic model framework.

All companies were carrying out ecodesign implementation projects and other sustainabilityrelated initiatives at the time of the realization of the workshops. Furthermore, these experts hold positions at their companies that allow them to actively participate in the core decision-making process regarding implementations in product development processes (e.g., Vice-President of Environment and Sustainability, the Product Environmental Specialist, Global Head of Environment, Health and Safety, among others). This enables them to adequately evaluate which types of rationale should be put forth in order to advance any sustainability-related activities in their organizations (i.e., building the business case for their particular organization).

The consolidated list of business performance outcomes from the SLR (Step 6) formed the theoretical basis of the workshop. The most recurrent outcomes were listed on a poster for prioritization. Initially, participants were asked to choose the three most relevant strategic-level decision-makers in their organizations if they were to present a business case for sustainability-oriented initiatives in product development (i.e., typically chief-level positions at large multinational organizations). This step is underpinned by the widely recognized need to tailor the business case argumentation to meet the requirements of different stakeholders $[7,23,63]$, which is reflected in the choices of which business performance outcomes to focus.

Next, participants were requested to identify the three to five most important business performance outcomes for each one of the selected decision-makers from the previous step. To aid the exercise, participants were invited to think about concrete cases of implementation projects carried out recently at their organization and how the most compelling arguments were put forth to the key decision-makers. Finally, the instantiated logic model framework from Phase 2 was presented to all participants and 3 to 5 examples of ecodesign management practices were highlighted. Participants were also given time and resources to think on the relationships between the logic model's components and use the business performance outcomes they had defined. Workshop participants were then invited 
to evaluate the usefulness and applicability [64] of the logic model framework at their organizations in an unstructured interview setting, pinpointing the strengths and weaknesses of the framework.

\section{Results and Discussion}

This section exhibits the results and provides discussion for each one of the research methodology phases. Section 4.1 presents the results and discussion for the development of a theoretical logic model framework, while Section 4.2 tackles the development of a ecodesign-specific logic model framework, lastly, Section 4.3 addresses the final phase of the research methodology on the evaluation of the ecodesign-specific logic model framework by industry experts in a workshop setup.

\subsection{Results and Discussion from the Development of a Theoretical Logic Model Framework (Phase 1)}

The SLR for logic models resulted in a total of 636 papers retrieved, with 126 unique results coming from Web of Science, 349 unique results from Scopus and 161 papers that were indexed in both electronic databases. Lastly, 87 papers were entirely read and finally selected, representing $33.8 \%$ of the papers analyzed in the previous step. If measured against the amount of papers retrieved from the databases, the 87 selected papers represent $13.7 \%$. Figure 4 illustrates the results achieved with the SLR on logic models, based on the application of the review protocol as described under Section 3.1.

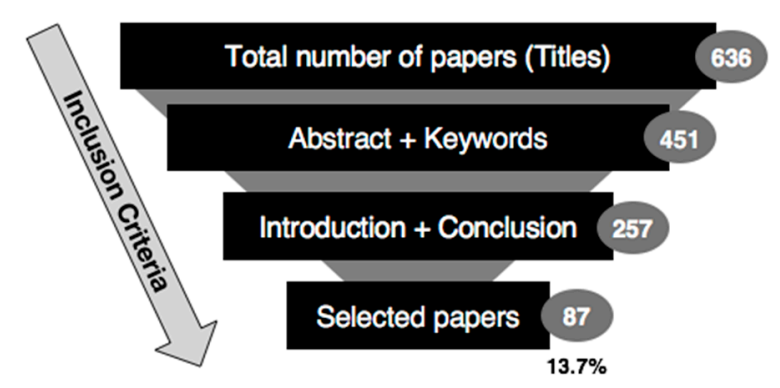

Figure 4. Summary of results from the SLR for logic models.

For each one of the 87 resulting papers, the elements were listed on an electronic database, along with the main topic addressed by the paper. There is a wide range of topics covered by the paper-with examples spanning different knowledge areas-and the logic models could be grouped into six topics: (i) healthcare interventions and public policies (23 papers); (ii) international and sustainable development (15 papers); (iii) educational interventions and programs (13 papers); (iv) organizational programs and evaluation-e.g., innovation, leadership, supply chain, R\&D, capacity development, ergonomics, collaboration employee wellness etc. (12 papers); (v) community-based program evaluation (8 papers) and (vi) academic and research-based programs ( 7 papers). The remaining 9 papers present and discuss generic logic models, with no connection with specific topics. The full database of categorized logic models with the description of their structural elements and the main topic they are addressing can be accessed via the link http:/ / www.ecodesign.dtu.dk/ProcessPerformance and as Supplementary Material of this paper.

Topics related to public policies dominate the use of the logic model to represent change and impact, in line with what was reported by the literature [31,65]. However, the corporate and business applications of logic models are still emerging and present a large potential for growth. Out of the 87 retrieved papers in the SLR, 12 of them (13.8\%) were tackling topics within the business sphere. This presents an opportunity for businesses to learn from several years of experience in stringent performance measurement practices and applications of logic models in the public and not-for-profit sectors. As sustainability performance measurement becomes increasingly more sophisticated and complex [66] and new stakeholders are being constantly engaged $[67,68]$, a collaborative and 
cross-sector development of logic models has the potential of bringing high value for the organization's integrated performance measurement.

The most recurrent elements within the logic model structures were: activities, outputs and outcomes, with some slight variations. The elements of outcomes were also represented differently across the reported logic models, as some of the studies have emphasized different timescales for the outcomes (namely long-, medium- and short-term outcomes). In general, when outcomes are split in different timescales, they offer a set of sequential preconditions [66]: short-term outcomes potentially representing changes in individuals and groups, medium-term ones connected to changes in skills and practices and long-term outcomes related to broader changes in conditions or states. Several studies also use the term "impact" to represent elements at a level close to what would be the long-term outcomes [69-71]. In general, the studies applying the term "impact" are usually referring to societal impacts on the long-run and, therefore, could be potentially used as a replacement for the long-term outcomes. Figure 5 displays the resulting theoretical and generic logic model framework. It is noteworthy that the input and the impact elements were not explicitly considered in the resulting logic model framework because both elements were not consistently reported across the reviewed logic models in the literature.

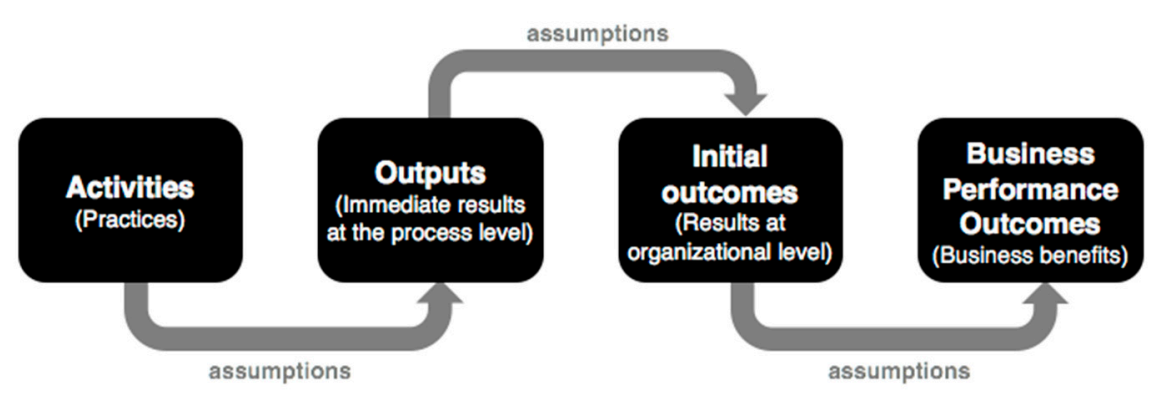

Figure 5. The resulting generic logic model framework for business cases.

Additionally, the role of assumptions is also presented in the logic models with varying degrees of importance. Some studies do not mention the assumptions that were made, while others provide a detailed account of the assumptions behind the logic model. To illustrate the idea behind the concept of assumptions in the logic models, consider the following management practice from the EcoM2: "develop a 'green' incentive scheme for the development of products with increased environmental performance" [16,19,42], which is considered to be an "activity" in the model. To evaluate its potential impact, it is necessary to draw some assumption in terms of its reach, scope and magnitude within the company. For example, an assumption could be "all employees are impacted by the incentive scheme developed", another assumption could be formulated as "only employees working in the R\&D structure will be initially impacted by the incentive scheme". Please note that each one of the assumption might lead to very different outputs, which in turn will lead to different initial outcomes and business performance outcomes.

The lack of explicit assumptions might hamper the credibility and validity of the logic model, as the relationships might become harder to be operationalized and understood by relevant stakeholders. With that, the resulting logic model framework not only covers the most recurrent elements in the literature, but also makes explicit delineation of assumptions. Additionally, it also marks the temporal distinction between the outcomes, placing them within a business context.

\subsection{Results and Discussion from the Instantiation of the Ecodesign-Specific Logic Model Framework (Phase 2)}

Each one of the steps in Phase 2 directly addressed each one of the elements of the generic logic model framework. Figure 6 shows the relationship between each one of the steps in Phase 2 and the correspondent logic model element they are addressing. The activities for the instantiated model were pulled from the Ecodesign Maturity Model (EcoM2) [19], while Step 3 performs a thematic analysis 
focused on deriving ecodesign management clusters to address the categorization of practices for the element "activity". Further on, Step 4 performs a complementary thematic analysis to generate a list of outputs and initial outcomes for the logic model. Finally, the SLR on business performance outcomes generated a database to fill in the final element of the logic model framework (business benefits).

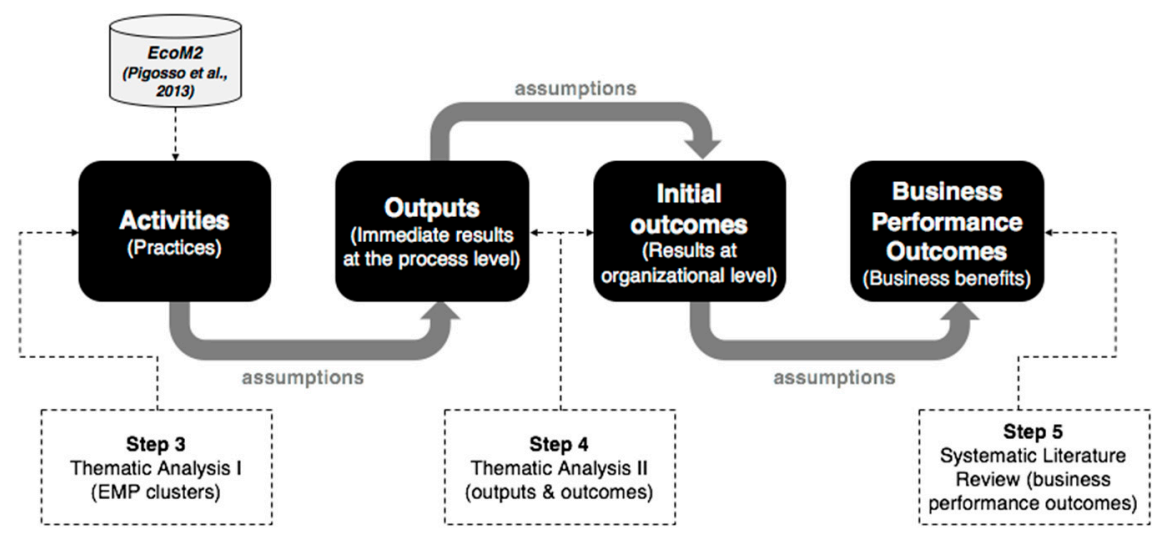

Figure 6. Relationship between the Steps 3, 4 and 5 in Phase 2 of the research methodology and the elements of the generic logic model framework.

\subsubsection{Instantiating the Activities of the Ecodesign-Specific Logic Model}

The thematic analysis (Thematic Analysis I, Step 3) carried out on the ecodesign management practices [19] gave rise to 11 distinct thematic clusters of practices. This step is addressing the element "activities (practices)" of the logic model on Figure 6. The clusters were designed and defined under an inductive approach, without any prior theoretical framework against which practices should fit. Therefore, the practices are sufficiently homogeneous within the clusters, at the same time they are appropriately heterogeneous across the clusters.

The clusters are particularly important to support managers in quickly identifying the practices by theme. This might allow decision-makers to draw better connections between the practices and their organization's context and structure. Table 1 shows the thematic clusters and corresponding examples of practices to illustrate the clusters. The development of outputs and initial outcomes, also shown in Table 1, are discussed under Section 4.2.2. The database displaying all the practices for all thematic clusters can be accessed via the link http:/ / www.ecodesign.dtu.dk/Process-Performance and as Supplementary Material of this paper. 
Table 1. Examples of practices in each one of the thematic clusters, with its outputs and initial outcomes.

\begin{tabular}{|c|c|c|c|c|c|}
\hline Cluster & Thematic Cluster & Number of Practices & Example of Practice $[16,19,42]$ & Outputs & Initial Outcomes \\
\hline 1 & $\begin{array}{l}\text { Environmentally-enhanced } \\
\text { technological strategy }\end{array}$ & 5 practices & $\begin{array}{l}\text { Identify and/or develop new technologies that can } \\
\text { contribute to improve the environmental } \\
\text { performance of the developed products }[16,19,42]\end{array}$ & $\begin{array}{l}\text { New environmentally- enhanced } \\
\text { technologies }\end{array}$ & $\begin{array}{l}\text { Products with } \\
\text { environmentally-enhanced technology }\end{array}$ \\
\hline \multirow{3}{*}{2} & \multirow{3}{*}{$\begin{array}{l}\text { Development of support } \\
\text { processes, training and } \\
\text { knowledge for ecodesign }\end{array}$} & \multirow{3}{*}{4 practices } & \multirow{3}{*}{$\begin{array}{l}\text { Get knowledge of how to develop products with } \\
\text { a better environmental performance }[16,19,42]\end{array}$} & \multirow{3}{*}{ Ecodesign knowledge } & Environmentally-enhanced products \\
\hline & & & & & $\begin{array}{c}\text { Informed/conscious } \\
\text { environmental-related decisions }\end{array}$ \\
\hline & & & & & Systematized trade-off analysis \\
\hline 3 & $\begin{array}{l}\text { Incentives and awareness } \\
\quad \text { for ecodesign }\end{array}$ & 2 practices & $\begin{array}{l}\text { Develop a "green" incentive scheme for the } \\
\text { development of products with increased } \\
\text { environmental performance }[16,19,42]\end{array}$ & Incentive schemes for ecodesign & $\begin{array}{l}\text { Employee motivation, engagement } \\
\text { and productivity }\end{array}$ \\
\hline \multirow{3}{*}{4} & \multirow{3}{*}{$\begin{array}{l}\text { Marketing and communication } \\
\quad \text { for ecodesign }\end{array}$} & \multirow{3}{*}{2 practices } & \multirow{3}{*}{$\begin{array}{l}\text { Elaborate and communicate recommendations to } \\
\text { consumers on how to improve the environmental } \\
\text { performance of the product during the use and } \\
\text { end-of-life phases }[16,19,42]\end{array}$} & \multirow{3}{*}{ Recommendations to consumers } & Consumer engagement and retention \\
\hline & & & & & $\begin{array}{l}\text { Employee motivation, engagement } \\
\text { and productivity }\end{array}$ \\
\hline & & & & & $\begin{array}{l}\text { Identification of ecodesign-related } \\
\text { opportunities and benefits }\end{array}$ \\
\hline \multirow{3}{*}{5} & \multirow{3}{*}{$\begin{array}{l}\text { End-of-life strategies, packaging } \\
\text { and operations }\end{array}$} & \multirow{3}{*}{5 practices } & \multirow{3}{*}{$\begin{array}{l}\text { Monitor the product environmental performance } \\
\text { during use and end-of-life }[16,19,42]\end{array}$} & $\begin{array}{l}\text { Environmental performance during } \\
\text { use and end-of-life }\end{array}$ & Information for end-of-life decisions \\
\hline & & & & \multirow[t]{2}{*}{ Consumer behavior data } & $\begin{array}{l}\text { Recommendations to } \\
\text { customers/stakeholders for use and } \\
\text { end-of-life }\end{array}$ \\
\hline & & & & & $\begin{array}{l}\text { Input data for product development } \\
\text { decision-making }\end{array}$ \\
\hline \multirow{2}{*}{6} & \multirow{2}{*}{$\begin{array}{l}\text { Strategic management of } \\
\text { ecodesign implementation }\end{array}$} & \multirow{2}{*}{9 practices } & \multirow{2}{*}{$\begin{array}{l}\text { Identify internal and external drivers for the } \\
\text { development of products with a better } \\
\text { environmental performance }[16,19,42]\end{array}$} & $\begin{array}{c}\text { Internal drivers for the } \\
\text { development of products with } \\
\text { better environmental performance }\end{array}$ & $\begin{array}{l}\text { Alignment and consistency with } \\
\text { internal drivers }\end{array}$ \\
\hline & & & & $\begin{array}{l}\text { External drivers for the } \\
\text { development of products with } \\
\text { better environmental performance }\end{array}$ & $\begin{array}{l}\text { Alignment and consistency with } \\
\text { external drivers }\end{array}$ \\
\hline 7 & $\begin{array}{l}\text { Portfolio management and } \\
\text { environmental trends }\end{array}$ & 4 practices & $\begin{array}{l}\text { Evaluate the environmental feasibility of new } \\
\text { product development projects }[16,19,42]\end{array}$ & $\begin{array}{l}\text { Environmental feasibility of new } \\
\text { product development } \\
\text { projects evaluated }\end{array}$ & $\begin{array}{l}\text { Input data for product development } \\
\text { decision-making }\end{array}$ \\
\hline
\end{tabular}


Table 1. Cont

\begin{tabular}{|c|c|c|c|c|c|}
\hline Cluster & Thematic Cluster & Number of Practices & Example of Practice $[16,19,42]$ & Outputs & Initial Outcomes \\
\hline \multirow{2}{*}{8} & \multirow{2}{*}{$\begin{array}{l}\text { Product development } \\
\text { management }\end{array}$} & \multirow{2}{*}{11 practices } & \multirow{2}{*}{$\begin{array}{l}\text { Engage relevant people from functions across the } \\
\text { company in the integration of environmental issues } \\
\text { into product development }[16,19,42]\end{array}$} & $\begin{array}{l}\text { Relevant people engaged in } \\
\text { ecodesign across the company }\end{array}$ & $\begin{array}{l}\text { Employee motivation, engagement } \\
\text { and productivity }\end{array}$ \\
\hline & & & & $\begin{array}{l}\text { Relevant people identified across } \\
\text { the company }\end{array}$ & $\begin{array}{l}\text { Employee awareness regarding } \\
\text { environmental issues }\end{array}$ \\
\hline \multirow{2}{*}{9} & \multirow{2}{*}{ Value chain management } & \multirow{2}{*}{3 practices } & \multirow{2}{*}{$\begin{array}{l}\text { Establish cooperation programs and joint goals with } \\
\text { suppliers and partners aiming to improve the } \\
\text { environmental performance of products }[16,19,42]\end{array}$} & \multirow{2}{*}{$\begin{array}{l}\text { Cooperation programs and joint } \\
\text { goals with suppliers and partners }\end{array}$} & $\begin{array}{c}\text { Superior value chain } \\
\text { environmentally-oriented integration }\end{array}$ \\
\hline & & & & & $\begin{array}{l}\text { Sharing of environmental information } \\
\text { among suppliers/partners }\end{array}$ \\
\hline \multirow{2}{*}{10} & \multirow{2}{*}{ Regulatory compliance } & \multirow{2}{*}{2 practices } & \multirow{2}{*}{$\begin{array}{l}\text { Collect information about legal issues and standards } \\
\text { related to the environmental performance of } \\
\text { products }[16,19,42]\end{array}$} & $\begin{array}{l}\text { Information about legal } \\
\text { issues collected }\end{array}$ & $\begin{array}{l}\text { Reaction and anticipation to } \\
\text { regulatory changes and trends }\end{array}$ \\
\hline & & & & $\begin{array}{l}\text { Information about } \\
\text { standards collected }\end{array}$ & $\begin{array}{l}\text { Potential for regulatory-driven } \\
\text { innovation in products and services }\end{array}$ \\
\hline 11 & $\begin{array}{l}\text { Program management and } \\
\text { ecodesign benchmarking }\end{array}$ & 4 practices & $\begin{array}{l}\text { Benchmark the environmental performance of } \\
\text { competitor products }\end{array}$ & $\begin{array}{l}\text { Benchmarks against } \\
\text { competitor products }\end{array}$ & $\begin{array}{c}\text { Identification of innovation } \\
\text { opportunities in products and services } \\
\text { based on benchmarks }\end{array}$ \\
\hline
\end{tabular}


Within this context, the ecodesign management practices can be defined and seen as activities that are embedded into the product development and related processes. Once these activities are carried out, they produce direct results (outputs) which, in turn, create changes or benefits (business performance outcomes) at a more aggregated level in an organization [46]. Figure 7 displays a hypothetical example of logic model for an ecodesign practice.

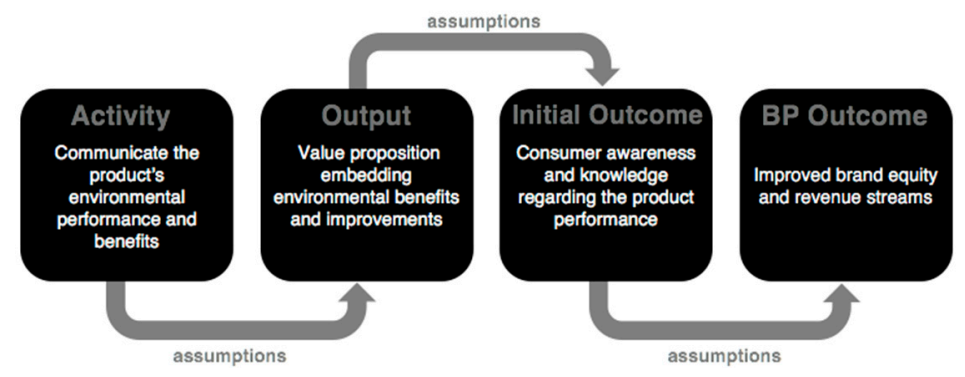

Figure 7. Hypothetical example of a logic model for an ecodesign-related initiative.

\subsubsection{Instantiating the Outputs and Initial Outcomes of the Ecodesign-Specific Logic Model}

The first thematic analysis underpinned the development of the second thematic analysis (Thematic Analysis II, Step 4). For each one of the clusters of practice, a set of outputs and initial outcomes were defined. This step is simultaneously addressing two elements of the logic model on Figure 6: "outputs" and "initial outcomes". The outputs and initial outcomes were defined in accordance to the generic logic model framework put forth as a result of the Phase 1 of the research methodology. This step is particularly important because it provides a preliminary repository of outputs and initial outcomes. Table 1 exhibits a selection of practices with their correspondent outputs and initial outcomes derived from the thematic analysis with triangulation. The full database containing all the outputs and initial outcomes defined in the thematic analysis can also be accessed via the link http:/ / www.ecodesign.dtu.dk/Process-Performance and as Supplementary Material of this paper.

\subsubsection{Instantiating the Business Performance Outcomes of the Ecodesign-Specific Logic Model}

Lastly, the last step of second phase of the research approach (Step 5) comprehended the performance of the SLR for business performance outcomes, which are the long-term outcomes representing the business benefits companies can potentially report. This step is addressing the element "business performance outcomes (business benefits)" of the logic model on Figure 6. Therefore, these are the outcomes that are specifically important for companies to decide for implementing a certain program or advancing a specific subject. The SLR for business performance outcomes resulted in a total of 199 papers retrieved. Fifty-four papers were selected and fully read (27.3\% of the total). Figure 8 illustrates the results of the SLR on the business performance outcomes.

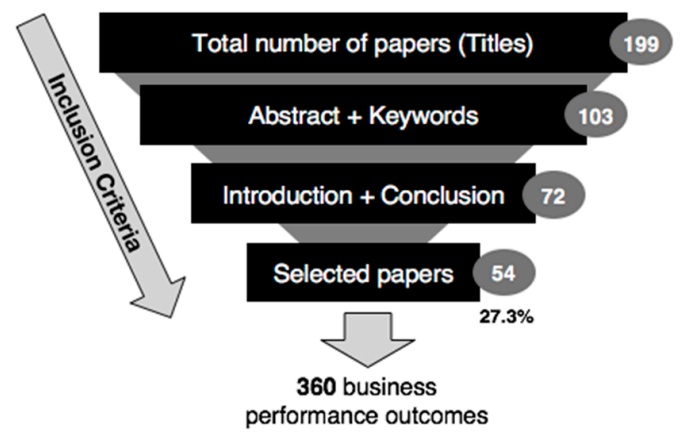

Figure 8. Summary of results from the SLR for business performance outcomes. 
The resulting 54 papers were carefully reviewed with the objective of extracting the business performance outcomes reported by the papers. In total, 360 business performance outcomes were identified, and the relevant information was extracted and recorded on an electronic spreadsheet. The business performance outcomes were then classified according to the triple bottom line dimensions. Subsequently, the business performance outcomes were classified in categories and sub-categories according to the main business topic they were associated [72]. Six categories emerged from the data for the classification of business performance outcomes: (i) regulatory; (ii) environmental and social engagement; (iii) marketing; (iv) learning and development; (v) efficiency and effectiveness and (vi) financial. The outcomes in the categories were split into a total of 21 sub-categories and duplicates were removed. The total number of unique business performance outcomes was 303 .

Figure 9 displays the distribution of business performance outcomes according to the dimensions of the triple bottom line, and Figure 10 exhibits the distribution of the consolidated business performance outcomes as per the categories and sub-categories of performance. The consolidated list of 6 categories and 21 sub-categories displayed on Figure 10 was used in the evaluation workshops with the industry experts. Finally, Table 2 presents examples of business performance outcomes that were retrieved from the SLR. The full database containing all the business performance outcomes be accessed via the electronic link http:/ / www.ecodesign.dtu.dk/Process-Performance and as Supplementary Material of this paper.

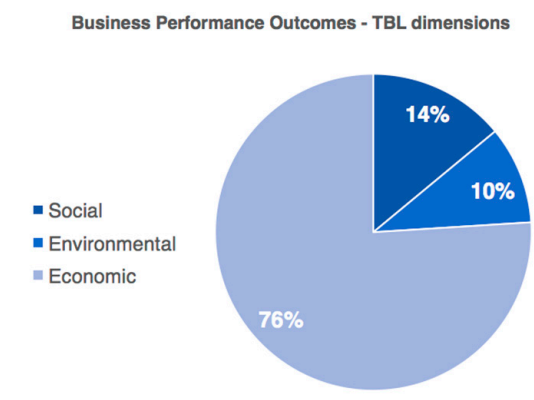

Figure 9. Classification of the business performance outcomes according to the the triple bottom line dimensions.

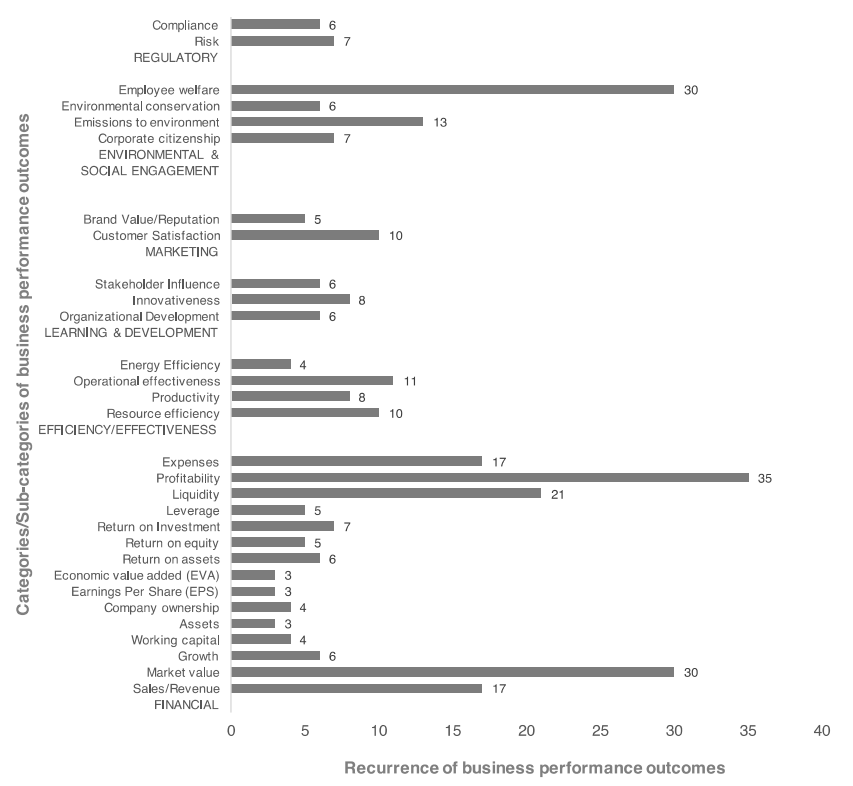

Figure 10. Distribution of the business performance outcomes according to the categories and sub-categories of performance (duplicates were removed from the total sum). Total number of business performance outcomes: 303. 
Table 2. Examples of business performance outcomes extracted from the SLR.

\begin{tabular}{cclc}
\hline TBL Dimension & Category & \multicolumn{1}{c}{ Business Performance Outcome } & Reference \\
\hline Economic & Marketing & Brand value & {$[73]$} \\
\hline Economic & Profitability & Company profitability & {$[74]$} \\
\hline Economic & Revenue & Revenue growth & {$[75]$} \\
\hline Economic & Customer satisfaction & Customer loyalty rate & {$[76]$} \\
\hline Social & Corporate citizenship & Community support/involvement & {$[77]$} \\
\hline Social & $\begin{array}{l}\text { Organizational } \\
\text { development }\end{array}$ & $\begin{array}{l}\text { Information dissemination } \\
\text { (i.e., enhancement of the quality of } \\
\text { decision-making/solution development) }\end{array}$ & {$[78]$} \\
\hline Social & Employee welfare & $\begin{array}{l}\text { Human capital investment (wages, } \\
\text { benefits, training and education) as } \\
\text { percentage of profit }\end{array}$ & {$[79]$} \\
\hline Environmental & $\begin{array}{c}\text { Emissions to } \\
\text { environment }\end{array}$ & Total emission of glasshouse gasses & {$[80]$} \\
\hline Environmental & Resource efficiency & Material consumption & [79] \\
\hline Environmental & Energy efficiency & Energy management ${ }^{1}$ & {$[81]$} \\
\hline
\end{tabular}

1 "This variable assesses rational use of energy; the adoption of internal measures of energy economy, including the substitution of equipment and other pollution sources; the substitution of pollutants and non-renewable sources for clean and renewable energy ones" [81].

\subsection{Results and Discussion from the Evaluation of the Ecodesign-Specific Logic Model Framework (Phase 3)}

This sub-section provides an initial summary of the evaluation procedure of the ecodesign-specific logic model framework with company experts, with the final framework presented in Figure 11 and evaluation summaries on Table 3 (companies' main characteristics) and Table 4 (summary of the main advantages and disadvantages). Subsequently, a more detailed account of strengths and weaknesses of the framework is provided under Sections 4.3.2 and 4.3.3. Under Section 4.3.4, a path forward for the application of the framework is outlined and discussed.

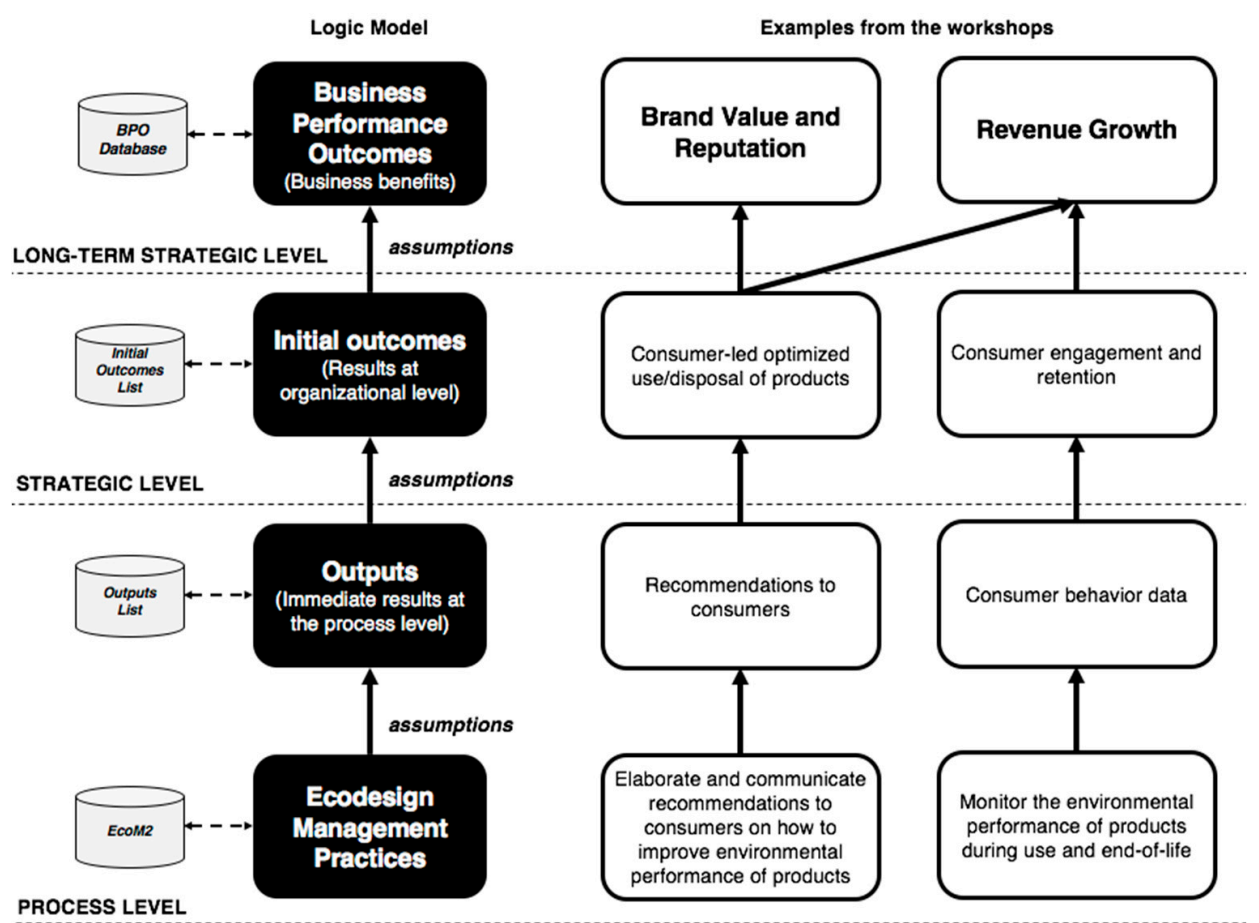

Figure 11. Consolidated version of the ecodesign-specific logic model framework. 


\subsubsection{Summary of the Evaluation of the Ecodesign-Specific Logic Model Framework}

Based on the data collected during the workshops with company experts, the theoretical logic model for business cases was revisited and changed to accommodate the suggested improvements. A few considerations were recurrent in all workshops and they have, therefore, underpinned the changes to the theoretical logic model that was initially defined (Section 3.1). In summary, the visual changes were mainly based on the positioning of the logic model elements and the removal from the input element. Experts suggested to display the logic model in a way that the levels at the organizational were explicit, making it more intuitive. Therefore, the elements of the ecodesign-specific logic model framework were rearranged in a hierarchical setting, with the activities representing the process-level, while the outputs, initial outcomes and business benefits are representing different levels of the corporate level.

Furthermore, experts corroborated what the analysis of management practices in the literature had suggested: the inputs to the ecodesign management practices are roughly homogeneous $[20,22]$ and therefore should not be explicitly differentiated in the model, as it would be a time-consuming and non-value adding activity. From an investment perspective, the implementation of the ecodesign management practices does not require a large set of different types of resources to be successfully carried out-i.e., the overwhelming majority of the ecodesign management practices are consistently dependent on a fixed set of inputs-namely information, people, organizational structure and information systems (both software and hardware), and this is consistent across the 51 practices. Therefore, the evaluation of inputs was deemed not necessary for a successful development of the business case for ecodesign. With that, Figure 10 displays the final structure of the logic model framework, along with examples that were raised during the workshop.

As previously mentioned under the research methodology section, the methodological setup regarding the evaluation workshops were designed in order to maximize the probability of replicating the results reported in this piece of research. Therefore, the results have a rather high degree of consistency, especially when replicating the research carried out in this paper by: (i) carefully following the same procedure have laid out in the research methodology and (ii) being able to access the same number of experts with a rather similar mix of backgrounds, experience and related industrial sectors, which is the main reason these aspects of the evaluation phase were highlighted on Table 3 and discussed accordingly.

\subsubsection{The Strengths of the Logic Model Approach for Deriving Ecodesign Business Cases}

The framework is suited for capturing and conceptualizing an initial business case at the process level and for directly aiding executives and employees in the way they currently think about the business returns of sustainability-related initiatives and programs. The logic model adds more as a visual account of the causal relations in the business case, linking activities in the process and the potential long-term outcomes. The logic model framework is also useful to pinpoint the types of evidence and data within the company (and across its value chain) that needs to be properly collected, if the company is not already doing so. The addition of data further validates and supports the claims and assumptions put forth in the logic model.

The logic model framework is also flexible enough to be readily embedded into a company's daily thinking and operation. In particular, for companies engaged in raising awareness regarding sustainability topics, the framework can be employed for e.g., workshops and other engaging co-development activities. The logic model was found to be particularly useful to creating a structured story for each one of the stakeholders, which is something in line with what the literature of logic models has prescribed [46]. This "storytelling" aspect of the logic model framework was appealing to several experts and allowed them to think on new strategies to get the attention of their intended target audience in terms of developing the business case for ecodesign. 
Table 3. Summary of the companies' main characteristics and related results from the evaluation procedure (Phase 3).

\begin{tabular}{|c|c|c|c|c|}
\hline Company & Industry & Roles Represented in the Workshop & $\begin{array}{c}\text { Prioritized Business Performance } \\
\text { Outcomes (Ranked) }\end{array}$ & $\begin{array}{c}\text { Main Internal Stakeholders for } \\
\text { the Ecodesign Business Case }\end{array}$ \\
\hline $\mathrm{A}$ & $\begin{array}{l}\text { Medical devices } \\
\text { and services }\end{array}$ & $\begin{array}{l}\text { Global Head of Environment, Health and } \\
\text { Safety (EHS) Development, with more than } \\
11 \text { years of work experience as ecodesign } \\
\text { program manager and leader }\end{array}$ & $\begin{array}{ll}\text { 1. } & \text { Growth (related to both sales } \\
\text { and market share) } \\
\text { 2. Risk } \\
\text { 3. } \\
\text { 4. } \text { Brand reputation } \\
\text { 5. Profitability }\end{array}$ & $\begin{array}{ll}\text { - } & \text { CEO } \\
\text { - } & \text { Director of Product } \\
\text { - } & \text { Development/Innovation } \\
& \text { Director of Operations }\end{array}$ \\
\hline B & $\begin{array}{l}\text { Automotive and } \\
\text { aerospace }\end{array}$ & $\begin{array}{l}\text { PhD Specialist on Design for Robustness, } \\
\text { holding over } 16 \text { years of experience in product } \\
\text { development and technology roadmapping; } \\
\text { Manager of R\&D development methods, with } \\
\text { more than } 12 \text { years of experience in product and } \\
\text { technology development, along with experience } \\
\text { in product/service-systems; }\end{array}$ & $\begin{array}{ll}\text { 1. } & \text { Profitability } \\
\text { 2. } & \text { Customer satisfaction } \\
\text { 3. "Air worthiness" } 1 \\
\text { 4. } \\
\text { 5. } & \text { Prowth } \\
\text { Productivity }\end{array}$ & 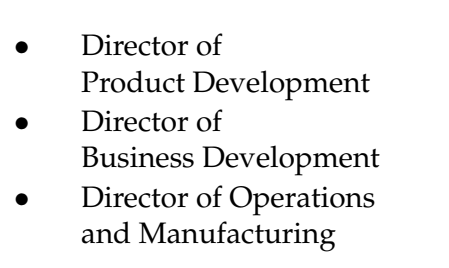 \\
\hline
\end{tabular}

- Vice-President of Environment and

Sustainability, holding more than 12 years of experience in executive roles;

- $\quad$ Product Environmental Specialist, with over 15 years of experience in leadership roles involving product development and management of ecodesign;

Equipment for construction and
related industries
- Technology Risk Analysis Leader, more than 21 years of experience in quality assurance, risk management/mitigation and product development processes;

- Sustainability Program Leader, with more than 11 years of experience in sustainable innovation and technology roadmapping and development.
1. Customer satisfaction

2. Total cost of ownership

3. Operational effectiveness

4. Profitability

5. Market share
- $\quad$ CEO

- Director of

Product Development

- Director of Marketing and Product Portfolio 
Table 4. Summary of the main advantages and disadvantages regarding application of the ecodesign-specific logic model framework for business cases.

\begin{tabular}{|c|c|c|}
\hline Company & $\begin{array}{l}\text { Main Strengths Regarding the Application of the } \\
\text { Ecodesign-Specific Logic Model Framework }\end{array}$ & $\begin{array}{l}\text { Main Weaknesses Regarding the Application of the } \\
\text { Ecodesign-Specific Logic Model Framework }\end{array}$ \\
\hline A & $\begin{array}{l}\text { - Suited for capturing and conceptualizing an initial business case } \\
\text { internal study } \\
\text { Potential for helping employees to structure their thoughts on } \\
\text { business benefits and elaborate working documents } \\
\text { - Lists of outputs, initial outcomes and business performance } \\
\text { outcomes are particularly useful as a point of departure for } \\
\text { further customization }\end{array}$ & $\begin{array}{l}\text { Quantification methods and evidence must be added to the logic } \\
\text { model rationale in order to derive a full-fetched business case } \\
\text { Language must be constantly adapted to fit the company's own } \\
\text { terminology/lexicon } \\
\text { - The model can quickly grow in size and complexity and should } \\
\text { be used on a step-by-step basis }\end{array}$ \\
\hline B & $\begin{array}{l}\text { - High readiness level in terms of embedding the framework into } \\
\text { the company's daily thinking and routine operations } \\
\text { - Useful for tailoring a specific "story" for each one of the many } \\
\text { important stakeholders of a business case for ecodesign } \\
\text { - Flexible and generic enough to be embedded into the company's } \\
\text { existing performance measurement systems } \\
\text { - Potential for making more diffuse/intangible practices more } \\
\text { operational and concrete }\end{array}$ & $\begin{array}{l}\text { - Potential conflicts and challenges when integrating multiple logic } \\
\text { model views for different audiences } \\
\text { - Concerns over the assumptions might arise and hamper the } \\
\text { development of a consolidated business case } \\
\text { The framework offers no support for developing the relationships } \\
\text { on data from the company's management systems }\end{array}$ \\
\hline $\mathrm{C}$ & $\begin{array}{l}\text { Potential for enhancing the development of business case with a } \\
\text { view of how things can change (improve) internally } \\
\text { - Relevant tool for internal awareness-raising workshops the } \\
\text { company is promoting on sustainability } \\
\text { - It is a communication tool to be readily incorporated into internal } \\
\text { materials and training resources } \\
\text { The practices' clusters are helpful for targeting groups of } \\
\text { stakeholders internally and aim at their daily concerns }\end{array}$ & $\begin{array}{l}\text { - The business case framework risk being too vague if assumptions } \\
\text { are not properly grounded and if business performance outcomes } \\
\text { are not carefully selected } \\
\text { The lead time for developing and applying the business case can } \\
\text { be long for consensus-oriented corporate cultures } \\
\text { To be a valuable tool, it requires a deep understanding of } \\
\text { organizational processes, product development and } \\
\text { ecodesign/EcoM2 framework }\end{array}$ \\
\hline
\end{tabular}


In general, the logic model framework can potentiate the discussion around the development of business cases for ecodesign, especially for companies that have been stuck in the sustainability conversations for a while. There is a strong role to be played by the framework as a communication tool to be embedded into internal materials, workshops and training resources. Moreover, the definition of thematic clusters of ecodesign management practices is particularly helpful towards targeting specific groups of stakeholders and aiming at their main daily activities/issues. In connection to that, the preliminary list of outputs, initial outcomes and business performance outcomes compose in important point of departure for companies to further apply and customize the business cases for their particular contexts.

\subsubsection{The Weaknesses of the Logic Model Approach for Deriving Ecodesign Business Cases}

In general, since developing the business case is mainly an argumentation process, language plays a crucial role. One of the drawbacks of the framework is that is still very qualitative in nature, and language must be constantly adapted and reviewed in order to employ the right company terminology/lexicon, so it can be widely recognized internally. Also, further investigation is required in order to derive a full and complete business case picture, especially in relation to quantifying the relationships and building a robust tool for decision-making processes. It must be noted that the logic model can also grow in size and complexity rather quickly, hinting that it should be used on a step-by-step basis or even focused on one particular thematic cluster at a time as not to overwhelm stakeholders or overload the cause-and-effect rationale.

Furthermore, there might be potential conflicts and difficulties in integrating multiple logic model views for different audiences or stakeholders into one shared vision. Even though it is crucial to establish one line of thinking for each one of the target groups, difficulties might arise when drawing a concise and broader picture of what the business case looks like. Concerns over assumptions and the need for operationalizing each one of the terms used in the business case are also current limitations of the framework. As it is now, the framework does not offer any support towards grounding the business case relationships on data from e.g., management systems or other sources. Therefore, a better connection with existing key performance indicators and other performance measurement initiatives within product development must be sought as one of the promising areas of further development of the framework.

\subsubsection{What Is Next? Applying the Ecodesign-Specific Logic Model Framework in Companies}

The ecodesign-specific logic model can be applied by companies in order to derive business cases aimed at advancing the ecodesign program internally. With that, an application procedure is proposed in alignment with how the EcoM2 is typically applied. However, this does not mean that the full implementation of the EcoM2 is a prerequisite for the application of the logic model framework for ecodesign. Companies can simply access all the information regarding the management practices, the clusters, outputs, initial outcomes and business performance outcomes and start structuring their own logic model framework, focused on specific areas of interest. The EcoM2 prescribes an application method with 4 steps, which are being represented here as an adaptation from [19], organized in two main phases, as described under Section 2.1.3. Figure 12 displays the schematic representation of the EcoM2 application method, with the main outputs and the positioning of the business case.

Since comparing the application of the business case framework in small and large companies was not the goal with this study, it is not possible to draw any fundamental conclusion from the data that have been collected. However, on a speculative note, we believe that the idiosyncrasies of startups and small and medium companies must be rigorously considered in the development of the ecodesign business case, and in particular when developing the assumptions, mainly because small and large companies may differ in several dimensions: (i) availability of data; (ii) stability of their business models and (iii) order of magnitude of impacts (e.g., $5 \%$ increase in sales might not 
be relevant for a small startup business, but might be a very significant sum for a big corporation), among other factors.

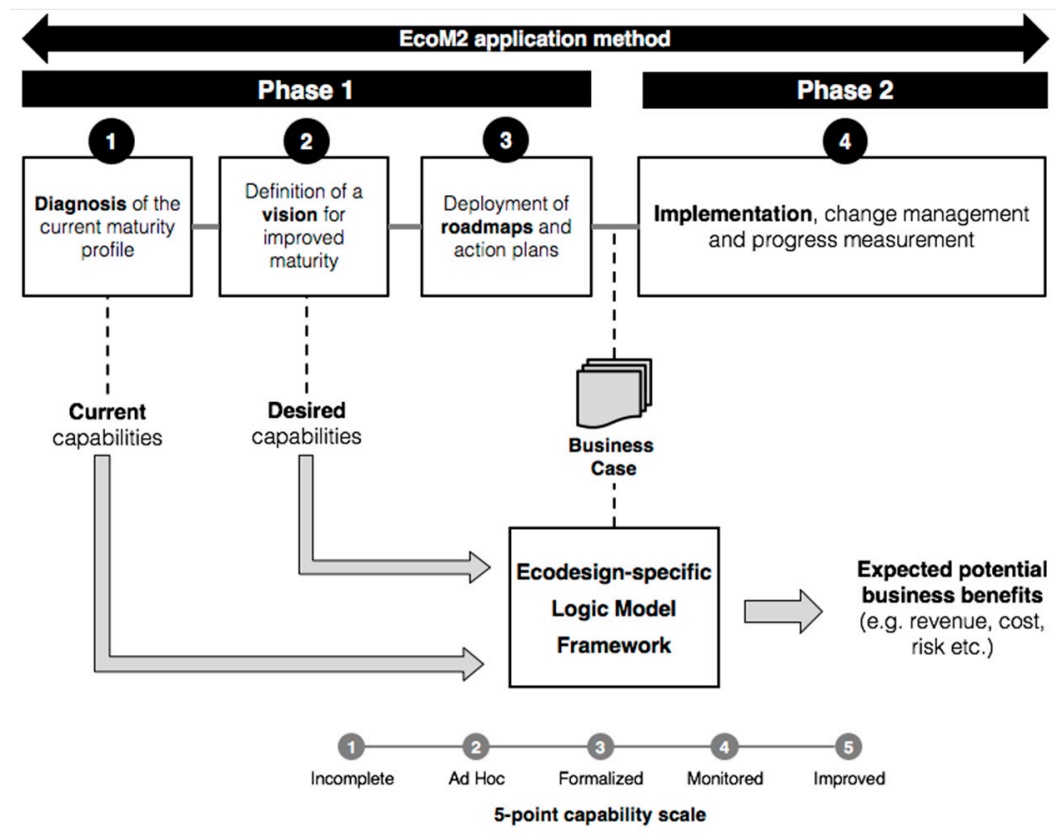

Figure 12. Schematic representation of the EcoM2 application method and the position of the business cases. Steps 1 through 4 adapted from [19].

In summary, this business case for ecodesign can be viewed as a first attempt towards linking the development of ecodesign capabilities—at the process level—with broader corporate performance indicators (business benefits). It implicitly links the efforts towards systematizing the activities within the product development process with the outcomes for the business. This is particularly important because product development processes are key to embedding sustainability in organizations, since it is believed that approximately $80 \%$ of the sustainability performance of a product is defined in the early stages of its product development [82]. Therefore, if companies want to move and align their agenda and contributions towards the sustainable development $[83,84]$, product development should be carefully considered and emphasized. In particular, capturing sustainability performance in product development is a complex and difficult endeavor [85-87] and if carried out inappropriately, misleading measures and wrong signals might be disseminated across the organization, which in turn results in poor decision-making [85]. In this sense, the logic model-based framework has the potential of properly addressing fundamental process-related aspects of the product development $[22,56,88]$ and turn them into an a priori (inferred) business case, as opposed to posteriori analyses of the results of previously implemented practices or projects.

\section{Final Remarks}

This research was geared towards answering two main research questions: (1) how does the implementation of ecodesign management practices can potentially affect corporate performance? (2) how can logic models support conceptualization and evaluation of the relationships between ecodesign practices and business benefits? A conceptual framework-based on logic models-was derived as a business case structure for ecodesign implementation. This was achieved by following a three-stage research methodology, organized in 6 steps. Two full systematic literature reviews were performed, coupled with two thematic analyses and a grounded theory approach. The resulting conceptual framework had its usefulness and applicability was then evaluated by 7 industry experts. 
In general, developing a business case is a context-dependent effort and should be carefully custom-built to fit its intended audience's language and general requirements. Based on the data gathered for this study, it is possible to argue that even the development of the relationships between the elements of a logic model should resonate with the company's strategic drivers and should be built with a view to improving its performance measurement systems over time. This means that the logic model framework might configure the first steps towards building the full-fetched business case rationale and support the collection of relevant data. The logic model does not represent an end in itself. It is a means to achieving the higher aim of developing consistent and data-driven business case for ecodesign. It is important to highlight that corporate performance is influenced by a wide range of different factors-both internal and external to the companies and their value chains-and the proposed framework accounts only for the potential effects of ecodesign on corporate performance. There is no pretension to capture the full range of influencing factors, which was initially deemed as impractical.

\subsection{Contributions to the Literature}

This research was exploratory in its nature and aimed at laying out the foundation to build consistent business case rationales through the lens of the theory of logic model. It is a first attempt towards qualitatively linking the development of ecodesign management capabilities with the potential business benefits. By addressing this topic, the contributions to the literature are manifold: (1) it defines a structured approach for depicting and visualizing intangible and somewhat fuzzy rationales for sustainability-oriented business cases; (2) aligns the theory of logic models with practical and readily implementable ecodesign-based applications within organizational spheres; (3) adds evidence on the suitability of applying logic models in corporate contexts, expanding the applications of the theory to different fields of knowledge; (4) offers a structural framework against which novel quantitative and qualitative methods can be potentially derived to assessing sustainability performance within a corporate context; (5) contributes to education in ecodesign and/or sustainable design, more broadly, by being embedded into the program curricula as an introductory framework aimed at developing business cases for action regarding ecodesign implementation (and other frameworks and quantitative methods could follow); and (6) directly contributes to the ecodesign theory and practice by laying out an ecodesign-instantiated logic model theory, which is readily available to be adapted and customized for further test and use in practice.

\subsection{Limitations and Future Research}

However, this research also presents limitations. These can be enumerated as follows: (1) the purely qualitative nature of this research might limit the tangibility of the results; (2) the research offers no guidance on how to specifically derive the relationships/assumptions connecting the elements or how to gather and apply corporate data within the logic model framework; (3) due to its exploratory nature, the evaluation procedure relied on an intense workshop-based interaction with companies, which enabled the capture of a wealth of details but was still constrained under the participants' background, experience and roles; (4) the logic model framework does not quantify changes in the capability levels of the practices (i.e., the goal of ecodesign implementation programs).

With a view to both addressing those limitations and developing the field further, several streams of future research could be derived: (a) explore methods for quantifying the relationships with a view to bringing dynamic elements into play and simulate different implementation routes; (b) develop guidelines for how to derived relationships between the business case elements and their underpinning assumptions and links with existing corporate management systems; (c) perform cross-industry or cross-national surveys, based on the logic model framework put forth here, in order to evaluate its usefulness and applicability in different contents and aim for higher results' generalizability power; (d) explicitly integrate the concept of capability into a quantitative simulation model so as to explore how changes in the capability levels might reflect on higher order business benefits; (e) investigate 
connections and synergies with indicators proposed by standards (e.g., ISO 14000, ISO 26000 etc.) and integrated reporting initiatives; (f) explore the potential implications for ecodesign/sustainable design education and how the framework can be adapted to become a teaching tool; and (g) conduct and analyze the actual implementation of the logic model framework in industrial cases with a view to enhancing its validity and applicability-based, for instance, on action research methods.

Supplementary Materials: The following are available online at http:/ /www.mdpi.com/2071-1050/10/6/2011/s1, Document (PDF) S1: full list of categorized logic models with the description of their structural elements and the main topic they are addressing (retrieved from the systematic literature review); Database (Excel) S2: full database of clusters, outputs and initial outcomes for the ecodesign management practices; Database (Excel) S3: full database with the business performance outcomes (retrieved from the systematic literature review).

Author Contributions: V.P.R. took the lead on writing the manuscript, designed the systematic literature reviews, analyzed data from the reviews, and planned and delivered the evaluation workshops. D.C.A.P. designed the overall research strategy for the study, supervised the systematic literature reviews and assisted the arrangement of the workshops with the companies. J.W.A. performed the systematic literature reviews besides designing and facilitating the evaluation workshops with the companies. T.C.M. designed the overarching research project and the particular research approach for the study, analyzed data from the systematic literature reviews and also contributed towards defining the workshops' setup and approach. All authors worked collectively in reviewing and improving earlier drafts of the manuscript.

Funding: This research was funded by CNPq (National Council for Scientific and Technological Development) in Brazil (Grant Number 200869/2014-0).

Acknowledgments: We explicitly express our cordial gratitude to the Technical University of Denmark (DTU) for their institutional support. Also, we extend our sincere appreciation to the STOSIP (Strategic, Tactical and Operational Implementation of Sustainability into the Innovation Process) project team. The project is based on collaborative research effort between Swedish and Danish institutions.

Conflicts of Interest: The authors declare no conflict of interest.

\section{References}

1. Dyllick, T.; Dyllick, T.; Hockerts, K.; Hockerts, K. Beyond the business case for corporate sustainability. Bus. Strateg. Environ. 2002, 11, 130-141. [CrossRef]

2. Grayson, D.; Howard, S. The Business Case for Being a Responsible Business. 2011. Available online: http: / /www.bitc.ie/wp-content/uploads/2015/11/The-Business-Case-for-Responsible-Business.pdf (accessed on 17 May 2018).

3. Haned, N.; Lanoie, P.; Plouffe, S.; Vernier, M.-F. Profitability of Ecodesign: An Economic Analysis; HEC Montréal: Montréal, QC, Canada, 2015; pp. 1-33.

4. IRRC Institute. Driving Revenue Growth through Sustainable Products and Services; IRRC Institute: New York, NY, USA, 2015.

5. Plouffe, S.; Lanoie, P.; Berneman, C.; Vernier, M.F. Economic benefits tied to ecodesign. J. Clean. Prod. 2011, 19, 573-579. [CrossRef]

6. Rochlin, S.; Bliss, R.; Jordan, S.; Kiser, C.Y. Project ROI: Defining the Competitive and Financial Advantages of Corporate Responsibility and Sustainability; ISSUELAB: New York, NY, USA, 2015.

7. Hart, S.L.; Milstein, M.B. Creating sustainable value. Acad. Manag. Exec. 2003, 17, 56-67. [CrossRef]

8. Porter, M.E.; Kramer, M.R. Strategy \& society: The link between competitive advantage and corporate social responsibility. Harv. Bus. Rev. 2006, 84, 78-92. [PubMed]

9. Henderson, R. Making the Business Case for Sustainability; Harvard Business School: Boston, MA, USA, 2015.

10. ISO. ISO 14.006-Environmental Management Systems: Guidelines for Incorporating Ecodesign; ISO: Rome, Italy, 2011.

11. Heras-Saizarbitoria, I.; Molina-Azorín, J.F.; Dick, G.P.M. ISO 14001 certification and financial performance: Selection-effect versus treatment-effect. J. Clean. Prod. 2011, 19, 1-12. [CrossRef]

12. Pigosso, D.C.A.; Ferraz, M.; Teixeira, C.E.; Rozenfeld, H. The deployment of product-related environmental legislation into product requirements. Sustainability 2016, 8, 332. [CrossRef]

13. Boks, C. The soft side of ecodesign. J. Clean. Prod. 2006, 14, 1346-1356. [CrossRef]

14. Boks, C.; Stevels, A. Essential perspectives for design for environment. Experiences from the electronics industry. Int. J. Prod. Res. 2007, 45, 4021-4039. [CrossRef] 
15. Rodrigues, V.P.; Pigosso, D.C.A.; McAloone, T.C. Process-oriented performance indicators for measuring ecodesign management practices. In Proceedings of the International Design Conference-DESIGN 2016, Dubrovnik, Croatia, 16-19 May 2016; pp. 443-452.

16. Rodrigues, V.P.; Pigosso, D.C.A.; McAloone, T.C. Measuring the implementation of ecodesign management practices: A review and consolidation of process-oriented performance indicators. J. Clean. Prod. 2017, 156, 293-309. [CrossRef]

17. Rodrigues, V.P.; Pigosso, D.C.A.; McAloone, T.C. Process-related key performance indicators for measuring sustainability performance of ecodesign implementation into product development. J. Clean. Prod. 2016, 139, 416-428. [CrossRef]

18. Handfield, R.B.; Melnyk, S.A.; Calantone, R.J.; Curkovic, S. Integrating environmental concerns into the design process: The gap between theory and practice. IEEE Trans. Eng. Manag. 2001, 48, 189-208. [CrossRef]

19. Pigosso, D.C.A.; Rozenfeld, H.; McAloone, T.C. Ecodesign maturity model: A management framework to support ecodesign implementation into manufacturing companies. J. Clean. Prod. 2013, 59, 160-173. [CrossRef]

20. Raffo, D.M.; Wakeland, W. Moving Up the CMMI Capability and Maturity Levels Using Simulation; Software Engineering Institute, Carnegie Mellon University: Pittsburgh, PA, USA, 2008; pp. 77-94.

21. Wetzstein, B.; Leitner, P.; Rosenberg, F.; Dustdar, S.; Leymann, F. Identifying influential factors of business process performance using dependency analysis. Enterp. Inf. Syst. 2011, 5, 79-98. [CrossRef]

22. Kueng, P. Process performance measurement system: A tool to support process-based organizations. Total Qual. Manag. 2000, 11, 67-85. [CrossRef]

23. Schaltegger, S.; Lüdeke-Freund, F. The "Business Case for Sustainability" Concept: A Short Introduction; Centre for Sustainability Management: Lüneburg, Germany, 2012.

24. Carroll, A.B.; Shabana, K.M. The Business Case for Corporate Social Responsibility: A Review of Concepts, Research and Practice. Int. J. Manag. Rev. 2010, 12, 85-105. [CrossRef]

25. Hahn, T.; Preuss, L.; Pinkse, J.; Figge, F. Cognitive Frames in Corporate Sustainability: Managerial Sensemaking with Paradoxical and Business Case Frames. Acad. Manag. Rev. 2014, 39, 463-487. [CrossRef]

26. Schaltegger, S.; Freund, F.L.; Hansen, E.G. Business cases for sustainability: The role of business model innovation for corporate sustainability. Int. J. Innov. Sustain. Dev. 2012, 6, 95-119. [CrossRef]

27. Besharov, D.J.; Call, D. Using Logic Models to Strengthen Performance Measurement. In Improving Public Services: International Experiences in Using Evaluation Tools to Measure Program Performance; Besharov, D.J., Baehler, K.J., Klerman, J.A., Eds.; Oxford University Press: Oxford, UK, 2017; p. 31.

28. Goldman, K.D.; Schmalz, K.J. Logic Models: The Picture Worth Ten Thousand Words. Health Promot. Pract. 2006, 7, 8-12. [CrossRef]

29. Seidman, G. Does SDG 3 have an adequate theory of change for improving health systems performance? J. Glob. Health 2017, 7, 010302. [CrossRef] [PubMed]

30. W.K. Kellogg Foundation. Logic Model Development Guide; W.K. Kellogg Foundation: Battle Creek, MI, USA, 2004.

31. Strycker, J. Logic Models as a Way to Support Online Students and Their Projects. J. Educ. Online 2016, 13, 135-150. [CrossRef]

32. Kaplan, S.A.; Garrett, K.E. The use of logic models by community-based initiatives. Eval. Program Plan. 2005, 28, 167-172. [CrossRef]

33. Luiz, J.V.R.; Jugend, D.; Jabbour, C.J.C.; Luiz, O.R.; de Souza, F.B. Ecodesign field of research throughout the world: Mapping the territory by using an evolutionary lens. Scientometrics 2016, 109, 241-259. [CrossRef]

34. Pigosso, D.C.A.; Pattis, A.T.; McAloone, T.C.; Rozenfeld, H. Deployment and implementation of the Grundfos' sustainability strategy by means of the Ecodesign Maturity Model. In Proceedings of the International Design Conference-DESIGN 2014, Dubrovnik, Croatia, 19-22 May 2014; pp. 1663-1670.

35. Pigosso, D.A.; Grandi, C.; Rozenfeld, H. Strategic implementation of design for environment at Embraer. In Proceedings of the 8th International Symposium on Environmentally Conscious Design and Inverse Manufacturing, Jeju, Korea, 4-6 December 2013; pp. 2-5.

36. Pigosso, D.C.; McAloone, T.C. Ecodesign Maturity Model as a Framework to Support the Transition towards ISO 14.001: 2015 Certification. In Proceedings of the 20th International Conference on Engineering Design (ICED15), Milan, Italy, 27-30 July 2015; pp. 1-10. 
37. Pigosso, D.C.A.; McAloone, T.C. Maturity-based approach for the development of environmentally sustainable product/service-systems. CIRP J. Manuf. Sci. Technol. 2016, 15, 33-41. [CrossRef]

38. Pigosso, D.C.; McAloone, T.C. Supporting the development of environmentally sustainable PSS by means of the ecodesign maturity model. Procedia CIRP 2015, 30, 173-178. [CrossRef]

39. Pigosso, D.C.; McAloone, T.C. Best practices for the integration of social sustainability into product development and related processes. Sustain. Innov. 2015, 2015, 1-4.

40. Gauthier, C. Measuring corporate social and environmental performance: The extended life-cycle assessment. J. Bus. Ethics 2005, 59, 199-206. [CrossRef]

41. Hutchins, M.J.; Sutherland, J.W. An exploration of measures of social sustainability and their application to supply chain decisions. J. Clean. Prod. 2008, 16, 1688-1698. [CrossRef]

42. Pigosso, D.C.A. Ecodesign Maturity Model: A Framework to Support Companies in the Selection and Implementation of Ecodesign Practices. Doctoral Thesis, Universidade de São Paulo, São Paulo, Brazil, 2012.

43. Chrissis, M.B.; Konrad, M.; Shrum, S. CMMI (Capability Maturity Model Integration): Guidelines for Process Integration and Product Improvement; Addison-Wesley Professional: Boston, MA, USA, 2011.

44. Silva, D.; De Silva, M.J.; Breuer, E.; Lee, L.; Asher, L.; Chowdhary, N.; Lund, C.; Patel, V. Theory of Change: A theory-driven approach to enhance the Medical Research Council's framework for complex interventions. Trials 2014, 15, 267. [CrossRef] [PubMed]

45. Millar, A.; Simeone, R.S.; Carnevale, J.T. Logic models: A systems tool for performance management. Eval. Program Plan. 2001, 24, 73-81. [CrossRef]

46. McLaughlin, J.A.; Jordan, G.B. Logic models: A tool for telling your programs performance story. Eval. Program Plan. 1999, 22, 65-72. [CrossRef]

47. Baehler, K.J.; Klerman, J.A. Measuring and Managing Farther along in the Logic Model. In Improving Public Services: International Experiences in Using Evaluation Tools to Measure Program Performance; Besharov, D.J., Baehler, K.J., Klerman, J.A., Eds.; Oxford University Press: Oxford, UK, 2017; p. 34.

48. Cooksy, L.J.; Gill, P.; Kelly, P.A. The program logic model as an integrative framework for a multimethod evaluation. Eval. Program Plan. 2001, 24, 119-128. [CrossRef]

49. Biolchini, J.; Mian, P.G.; Candida, A.; Natali, C. Systematic Review in Software Engineering; University of Rio de Janeiro: Rio de Janeiro, Brazil, 2005.

50. Glaser, B.G.; Strauss, A.L. The Discovery of Grounded Theory: Strategies for Qualitative Research; Aldine Transaction: New Brunswick, NJ, USA, 1967.

51. Corbin, J.; Strauss, A. Basics of Qualitative Research: Techniques and Procedures for Developing Grounded Theory, 2nd ed.; SAGE Publications: Thousand Oaks, CA, USA, 1988.

52. Greckhamer, T.; Koro-Ljungberg, M. The erosion of a method: Examples from grounded theory. Int. J. Qual. Stud. Educ. 2005, 18, 729-750. [CrossRef]

53. Braun, V.; Clarke, V. Using thematic analysis in psychology Using thematic analysis in psychology. Qual. Res. Psychol. 2006, 3, 77-101. [CrossRef]

54. Walker, D.; Myrick, F. Grounded Theory: An Exploration of Process and Procedure. Qual. Health Res. 2006, 16, 547-559. [CrossRef] [PubMed]

55. Bashor, H.W. Content analysis of short, structured texts: The need for multifaceted strategies. In Determination of Information and Tenor in Texts: Multidisciplinary Approach to Discourse; Lagerwerf, L., Spooren, W., Degand, L., Eds.; Stichting Neerlandistiek VU: Amsterdam, The Netherlands, 2003; p. 322.

56. Driva, H.; Pawar, K.S.; Menon, U. Performance evaluation of new product development from a company perspective. Integr. Manuf. Syst. 2001, 12, 368-378. [CrossRef]

57. Vergidis, K.; Turner, C.J.; Tiwari, A. Business process perspectives: Theoretical developments vs. real-world practice. Int. J. Prod. Econ. 2008, 114, 91-104. [CrossRef]

58. Driva, H.; Pawar, K.S.; Menon, U. Measuring product development performance in manufacturing organisations. Int. J. Prod. Econ. 2000, 63, 147-159. [CrossRef]

59. Tuckett, A.G. Applying thematic analysis theory to practice: A researcher's experience. Contemp. Nurse 2005, 19, 75-87. [CrossRef] [PubMed]

60. Attride-Stirling, J. Thematic networks: An analytic tool for qualitative research. Qual. Res. 2001, 1, $385-405$. [CrossRef]

61. Kitto, S.C.; Chesters, J.; Grbich, C. Quality in Qualitative Research. Med. J. Aust. 2008, 4, 243-246. 
62. Smaling, A. Varieties of methodological intersubjectivity-The relations with qualitative and quantitative research, and with objectivity. Qual. Quant. 1992, 26, 169-180. [CrossRef]

63. Salzmann, O.; Ionescu-Somers, A.M.; Steger, U. The business case for corporate sustainability: Literature review and research options. Eur. Manag. J. 2005, 23, 27-36. [CrossRef]

64. Dul, J.; Hak, T. Case Study Methodology in Business Research, 1st ed.; Elsevier Ltd.: New York, NY, USA, 2008.

65. De-Regil, L.M.; Peña-Rosas, J.P.; Flores-Ayala, R.; Jefferds, M. Development and use of the generic $\mathrm{WHO} / \mathrm{CDC}$ logic model for vitamin and mineral interventions in public health programmes. Public Health Nutr. 2017, 17, 634-639. [CrossRef] [PubMed]

66. Allen, W.; Cruz, J.; Warburton, B.; Allen, W. How Decision Support Systems Can Benefit from a Theory of Change Approach. Environ. Manag. 2017, 59, 956-965. [CrossRef] [PubMed]

67. Hornik, K.; Cutts, B.; Greenlee, A. Community Theories of Change: Linking Environmental Justice to Sustainability through Stakeholder Perceptions in Milwaukee (WI, USA). Int. J. Environ. Res. Public Health 2016, 13, 979. [CrossRef] [PubMed]

68. Lee, S.; Kim, Y. Antecedents and Consequences of Firms' Climate Change Management Practices: Stakeholder and Synergistic Approach. Sustainability 2015, 7, 14521-14536. [CrossRef]

69. Serowoky, M.L.; George, F.N.P.N. Using the Program Logic Model to Evaluate ¡Cuídate!: A Sexual Health Program for Latino Adolescents in a School-Based Health Center. Worldviews Evid.-Based Nurs. 2015, 12, 297-305. [CrossRef] [PubMed]

70. Thomson, H.; Thomas, S. Social Science \& Medicine Developing empirically supported theories of change for housing investment and health. Soc. Sci. Med. 2015, 124, 205-214. [PubMed]

71. O'Keefe, C.M.; Head, R.J. Application of logic models in a large scientific research program. Eval. Program Plan. 2011, 34, 174-184. [CrossRef] [PubMed]

72. Pedersen, E.R.G.; Sudzina, F. Which firms use measures? Int. J. Oper. Prod. Manag. 2012, 32, 4-27. [CrossRef]

73. Svensson, G.; Ferro, C.; Carlos Sosa Varela, J.; Padin, C.; Wagner, B. A Triple Bottom Line Dominant Logic for Business Sustainability: Framework and Empirical Findings. J. Bus. Bus. Mark. 2016, 23, 153-188. [CrossRef]

74. Keeble, J.J.; Topiol, S.; Berkeley, S. Using indicators to measure sustainability performance at a corporate and project level. J. Bus. Ethics 2003, 44, 149-158. [CrossRef]

75. Gulamhussen, M.A.; Pinheiro, C.; Sousa, R. The Influence of Managerial Ownership on Bank Market Value, Performance, and Risk: Evidence from Banks Listed on the Stoxx Global Index. J. Int. Financ. Manag. Account. 2012, 23, 121-153. [CrossRef]

76. Dossi, A.; Patelli, L. You learn from what you measure: Financial and non-financial performance measures in multinational companies. Long Range Plan. 2010, 43, 498-526. [CrossRef]

77. Schulz, S.A.; Flanigan, R.L. Developing competitive advantage using the triple bottom line: A conceptual framework. J. Bus. Ind. Mark. 2016, 31, 449-458. [CrossRef]

78. Wang, W.-T. Evaluating organisational performance during crises: A multi-dimensional framework. Total Qual. Manag. Bus. Excell. 2012, 23, 673-688. [CrossRef]

79. Subramanian, N.; Gunasekaran, A. Cleaner supply-chain management practices for twenty-first-century organizational competitiveness: Practice-performance framework and research propositions. Int. J. Prod. Econ. 2015, 164, 216-233. [CrossRef]

80. Kocmanová, A.; Šimberová, I. Determination of environmental, social and corporate governance indicators: Framework in the measurement of sustainable performance. J. Bus. Econ. Manag. 2014, 15, 1017-1033. [CrossRef]

81. Fonseca, S.A.; Chiappetta Jabbour, C.J. Assessment of business incubators green performance: A framework and its application to Brazilian cases. Technovation 2012, 32, 122-132. [CrossRef]

82. McAloone, T.; Bey, N. Environmental Improvement through Product Development: A Guide; Danish Environmental Protection Agency: Copenhagen, Denmark, 2009.

83. United Nations. Global Sustainable Development Report 2016; United Nations: New York, NY, USA, 2016.

84. United Nations. Global Compact Guide to Corporate Sustainability 2014; United Nations: New York, NY, USA, 2014.

85. Costa, J.M.H.; Oehmen, J.; Rebentisch, E.; Nightingale, D. Toward a better comprehension of Lean metrics for research and product development management. RED Manag. 2014, 44, 370-383.

86. Loch, C.H.; Tapper, U.S. Implementing a strategy-driven performance masurement system for an applied research group. J. Prod. Innov. Manag. 2002, 19, 185-198. [CrossRef] 
87. Rodrigues, V.P.; Morioka, S.N.; Pigosso, D.C.A.; de Carvalho, M.M.; McAloone, T.C. Exploring the dynamic and complex integration of sustainability performance measurement into product development. In Proceedings of the International Design Conference-DESIGN 2016, Dubrovnik, Croatia, 16-19 May 2016; pp. 433-442.

88. Rozenfeld, H. Reference model for managing product development. In Sustainability in Manufacturing: Recovery of Resources in Product and Material Cycles; Seliger, G., Ed.; Springer: Berlin, Germany, 2007; pp. 193-206. 